DOI 10.23947/2414-1143-2020-22-2-40-49

UDC 316.7 (470.6)

\title{
DYNAMICS OF INTER-REGIONAL POPULATION MIGRATION IN THE SOUTH OF RUSSIA
}

\author{
(C) Alexander V. Dzhioev \\ Vladikavkaz Scientific Centre of the Russian Academy of Sciences, \\ Vladikavkaz, Russian Federation \\ dzhioevsasha@gmail.com
}

In December 2019, an epidemic of a new acutely infectious disease broke out in the Chinese city of Wuhan, which in two to three months turned into a pandemic of the coronavirus infection COVID-19. The epidemiological, economic, environmental, humanitarian and political crisis has begun on the planet. The world has never come across a similar situation. This is much more serious than what humanity has experienced in last epidemics, when they spread from one continent to another for decades. In early summer 2020, more than 6.5 million people were found to have coronavirus in the world, according to Johns Hopkins University. The article gives a general assessment of the enormous losses of the world economy and the economies of individual States that arose as a result of quarantine during the coronavirus pandemic of 2020, it is shown that, compared with previous crises, this one will be more destructive for the labor market and the exit from it will be longer. The coronavirus epidemic has become a powerful challenge for the Russian labor market. It is concluded that the deterioration of the situation in the Russian economy due to the coronavirus pandemic will lead to increased interregional migration in the coming years, which will negatively affect the parameters of the demographic situation and the quality of the labor market in most of the North Caucasian regions of Russia, and the predicted persistence of high unemployment is associated with high threats to socio-political instability and the growth of social conflict. The author formulated a number of proposals on mitigation of economic consequences of the epidemic and controlling the outflow of working-age population from the regions of the North Caucasus.

Key words: Covid-19 coronavirus pandemic, unemployment rate in Russia, population migration from the regions of the North Caucasus, mitigation of economic consequences of the epidemic.

\section{[А.В. Джиоев Динамика межрегиональной трудовой миграции населения на Юге России]}

В декабре 2019 года в китайском городе Ухань вспыхнула эпидемия новой остро заразной болезни, которая за два-три месяца переросла в пандемию коронавирусной инфекции COVID-19. На планете начался эпидемиологический, экономический, экологический, гуманитарный и политический кризис. Никогда прежде мир не сталкивался с подобной ситуацией. Это гораздо серьезнее того, что человечество пережило в прошлые эпидемии, когда они из одного континента на другой распространялись десятилетиями. В начале лета 2020 года коронавирус в мире обнаружен более чем у 6,5 млн человек, свидетельствуют данные университета Джонса Хопкинса. Россия находится на третьем месте по общему числу выявленных случаев заболеваемости, а отдельные регионы Северного Кавказа попали в топ самых зараженных. Всего в мире умерло около 400000 больных COVID-19. B статье дана общая оценка колоссальных потерь мировой экономики и экономик отдельных государств, возникших вследствие карантина в период пандемии коронавируса 2020 года, показано, что по сравнению с прежними кризисами этот окажется более разрушительным для рынка труда, а выход из него будет более продолжительным. Эпидемия коронавируса стала мощнейшим вызовом и для российского рынка труда. Сделаны выводы о том, что ухудшение ситуации в российской экономике из-за пандемии коронавируса приведет в ближайшие годы к усилению межрегиональной миграции, что негативно скажется на параметрах демографической ситуации и качестве рынка труда большинства СевероКавказских регионов России, а прогнозируемое сохранение высокой безработицы таит в себе высокие угрозы общественно-политической нестабильности и роста социальной конфликтогенности. Автором сформулирован ряд предложений по сглаживанию экономических последствий эпидемии и сдерживанию оттока трудоспособного населения из регионов Северного Кавказа.

Ключевые слова: пандемия коронавируса Covid-19, уровень безработицы в России, миграция населения из регионов Северного Кавказа, сглаживание экономических последствий эпидемии. 
Alexander V. Dzhioev - Junior Research Fellow, Laboratory of Applied Sociology and Conflictology, Vladikavkaz Scientific Centre of the Russian Academy of Sciences, Vladikavkaz, Russian Federation.

Джиоев Александр Валерьевич - младший научный сотрудник, Лаборатория прикладной социологии и конфрликтологии, Владикавказский научный центр Российской академии наук, е. Владикавказ, Российская Федерация.

The modern world economy has entered a systemic crisis associated with the introduction of national quarantine measures in almost all countries of the world, caused by the unprecedented rapid spread of a new health-threatening coronavirus Covid-19.

The world has not known yet the same rate of spread of the disease, which has grown into a pandemic in two to three months since the beginning of 2000 . And also, for the first time in the history of mankind, there was an almost simultaneous suspension of production in virtually all sectors of the economy, and the business activity of companies, even global ones, began to fall. The world gross domestic product (GDP) began to decline rapidly. "Every month of total quarantine and social distancing reduces the annual growth in wealth of any country by about 2\%." This information is given by the experts from the Organization for Economic Cooperation and Development (OECD) in their last May report, worsening their March forecast by four times: then they considered that maintaining quarantine, self-isolation and social distancing of people will reduce the GDP of countries by an average of half a percent [4]. The world GDP, according to the World Bank (WB) reports, amounted to US \$ 85.8 trillion in 2019. It is easy to calculate the projected losses today at $2 \%$, they will amount to 1.716 trillion US dollars. This is about half of Germany's GDP, the largest EU national economy (\$3.997 trillion) and more than Canada's GDP of $\$ 1.71$ trillion, Russia's GDP of $\$ 1.66$ trillion, the GDP of South Korea which is $\$ 1.62$ trillion. And this is more than the total GDP of 2019 of such large countries as, for example, Mexico and Spain combined [16].

For five consecutive months all national economies have been slowing down, the streets of metropolises were empty, hotels, restaurants and many shops were closed, tens of millions of people were left without work and lost their livelihoods. It is noteworthy that residents of 200 States, both the largest and the smallest, suffered from the crisis. So, the US economy with GDP of 20.5 trillion US dollars, according to estimates by the International Monetary Fund (IMF), will decrease by $5.9 \%$, Italy's GDP by $9.1 \%$; the French economy will shrink by 7.2\%; Germany's economy will shrink by $7 \%$ [11]. The pan-European GDP, according to IMF experts, will decrease by $7.5 \%$ in 2020 . And the Central Bank of the European Union admits that the fall in GDP at the end of the year will reach $12 \%$ in 19 out of 26 eurozone countries, because according to Eurostat, the EU economy has already decreased by $3.5 \%$ in the first three months of 2020 [2]. In the IMF report it is noted that the European Union will experience such a decline for the first time in its existence, and China for the first time in almost half a century. In their projection of the development of the global economy after the pandemic, IMF economists consider that if business activity resumes in the second half of 2020, next year's economic activity will not cover the losses associated with the Covid-19 coronavirus epidemic, despite the fact that the world is going to spend at least another 10 trillion dollars to combat the crisis [6]. And the UN leadership considers that the economies of developing countries, which include Russia, India, Mexico and several other States in the world, will suffer from the introduction of stringent quarantine measures even stronger than developed economies. The UN calls on rich countries to help developing States in the framework of special support programs and general crisis measures, estimated by the UN at 2.5 trillion dollars [5]. And it is difficult to disagree with these arguments, since the world has an unprecedented outflow of capital from the markets of developing countries, 
four times higher than the similar reaction during the financial crises of 1998-1999, 20082009, and 2014-2015. The size of capital outflows from emerging markets amounted to almost $\$ 100$ billion in March alone [6].

The crisis we are experiencing, according to many world experts, will be the deepest since the Great Depression of the 1930s. It could throw away the world economy to the back of the last century and nullify all economic development efforts for two decades.

The history of human development shows that crises caused by epidemics often lead to interstate, interracial and interethnic disunity, which leads to socio-political instability, an increase in nationalism and protectionism, and most importantly, the rapid impoverishment of the vast masses of workers. That is why interracial unrest began in the United States, and in the richest country in the world, more than 20 million people applied for unemployment benefits in May alone. During the quarantine, in the world's most attractive country for labor migration, exactly as many jobs disappeared in just one month as were created over the past decade [7].

The number of unemployed citizens also rose sharply in Russia, as evidenced by data on the unemployment rate. In January-March 2020, the unemployment rate in Russia was unchanged, at 4.7\% [3], 4.6\% [8] and 4.7\% [12], respectively. However, in April, the number of unemployed in Russia increased by more than from 800 thousand people to 4.3 million people or 5.8\% [8]. According to the Confederation of Labor of Russia, unemployment in Russia had reached 8 million people by summer, and according to the founder of the leading Internet service Superjob A. Zakharov, the real number in the country is about 10 million people [12].

In the regions of Russia, where employment is mainly associated with small businesses temporarily closed due to quarantine, in our opinion, we can expect a wave of official bankruptcy and mass layoffs, a sharp drop in living standards, an aggravation of sociopolitical instability and an increase in social conflict against the background of an epidemic, the prospects for a complete exit from which are still unpredictable. These conclusions are based, first of all, on the history of the plague riot in Sevastopol 190 years ago. Then there was a popular uprising, which was provoked by quarantine measures against the spread of the cholera epidemic, which the authorities initially mistook for a plague. The riot was the first in a chain of cholera protests that swept through many regions of Russia of the 19th century. The inhabitants of Sevastopol, driven to despair, formed armed groups of volunteers who were preparing for an armed rebuff of the cordon of the city. From the hostilities that could blow up the situation in the city and in the navy, the city was restrained by the fact that the cordon soldiers and many officers sympathized with the inhabitants, and the volunteer units themselves were formed under the leadership of the retired military.

According to IMF forecasts, coinciding with the official forecasts of the Russian Government, Russia's GDP will decrease by 5.5\% in 2020, and in 2021 it will increase by about 2\%. A slowdown in economic activity will inevitably lead to an increase in unemployment, the level of which, according to the forecast of the Ministry of Economic Development will fall to $5.4 \%$ in 2021 , to $4.9 \%$ in 2022 , and will return to the level of the beginning of 2020 only in 2023.

However, a number of Russian experts predict that real unemployment in Russia by the fall of 2020 could grow to 20 million people [12]. Such a fall in the labor market due to the economic downturn can only strengthen interregional labor migration, which, even before the epidemiological crisis, as shown in our studies, had led to a deterioration of the demographic situation in the North Caucasus regions of Russia with a high level of chronic unemployment [13-15].

So, according to official data of Rosstat (Table 1), the total population of the North Caucasian Federal District (NCFD) during 01.01.2018-01.01.2019 increased by 43,267 people: from $9,845,114$ to $9,866,748$ people or by $0.4 \%$. 
Table 1. Dynamics of the permanent population of Russia and the regions of the South of Russia as of January 1, 2018-2019

\begin{tabular}{|c|c|c|c|c|c|c|}
\hline \multirow{3}{*}{ Table 1.2} & \multicolumn{3}{|c|}{ As of January 1, 2019} & \multicolumn{3}{|c|}{ As of January 1, 2018} \\
\hline & \multirow{2}{*}{$\begin{array}{l}\text { The entire } \\
\text { population }\end{array}$} & \multicolumn{2}{|c|}{ including: } & \multirow{2}{*}{$\begin{array}{l}\text { The entire } \\
\text { population }\end{array}$} & \multicolumn{2}{|c|}{ including: } \\
\hline & & urban & rural & & urban & rural \\
\hline Russian Federation & $\begin{array}{r}146780 \\
720\end{array}$ & $\begin{array}{r}109453 \\
533\end{array}$ & $\begin{array}{r}37327 \\
187\end{array}$ & 146830576 & 109390216 & 37440360 \\
\hline $\begin{array}{l}\text { Southern Federal } \\
\text { District }\end{array}$ & $\begin{array}{r}16454 \\
550 \\
\end{array}$ & 10316730 & 6137820 & 16448201 & 10300616 & 6147585 \\
\hline $\begin{array}{l}\text { North Caucasian } \\
\text { Federal District }\end{array}$ & 9866748 & 4947172 & 4919576 & 9845114 & 4920139 & 4924975 \\
\hline $\begin{array}{l}\text { The Republic of } \\
\text { Dagestan }\end{array}$ & 3086126 & 1396715 & 1689411 & 3075006 & 1390196 & 1684810 \\
\hline $\begin{array}{l}\text { The Republic of } \\
\text { Ingushetia }\end{array}$ & 497393 & 275891 & 221502 & 492718 & 272920 & 219798 \\
\hline $\begin{array}{l}\text { The Kabardino- } \\
\text { Balkarian Republic }\end{array}$ & 866219 & 451002 & 415217 & 866023 & 451170 & 414853 \\
\hline $\begin{array}{l}\text { The Karachay- } \\
\text { Cherkess Republic }\end{array}$ & 465563 & 199465 & 266098 & 465934 & 199344 & 266590 \\
\hline $\begin{array}{l}\text { The Republic of } \\
\text { North Ossetia-Alania }\end{array}$ & 699253 & 449873 & 249380 & 700509 & 450369 & 250140 \\
\hline $\begin{array}{l}\text { The Chechen } \\
\text { Republic }\end{array}$ & 1456951 & 534883 & 922068 & 1446966 & 518031 & 928935 \\
\hline Stavropol Territory & 2795243 & 1639343 & 1155900 & 2797958 & 1638109 & 1159849 \\
\hline
\end{tabular}

\section{The source: [10]}

As the data of Table 2 show, the highest indicators of negative migration of the population were observed in the Republic of Dagestan, the population of which in 2018 increased by 22,241 people, despite the fact that more than 11 thousand people left their republic. Negative migration is observed in all regions except Ingushetia, but in three regions of the North Caucasus Federal District it is threatening the demographic situation. Thus, in the Republic of North Ossetia-Alania there was the second largest negative migration growth after Dagestan of 4,512 people, which could not cover the natural population growth of 2,000 people. The number of Karachay-Cherkessia decreased by 742 people as a result of the migration outflow of the population of 1559 people. And the population of Stavropol Territory decreased by 543 , despite the fact that in the region there was both a natural decline of 1,400 people and a negative migration of 4,031 people. Only in the Republic of Ingushetia there is a demographically favorable situation: the total population growth of 9,350 people is ensured by a natural increase of 6,500 people and migration of the population to the region, estimated by Rosstat, of 2,850 people.

Table 2. Change in the permanent population of Russia and the regions of the South of Russia by components as of January 1, 2018-2019

\begin{tabular}{|c|c|c|c|c|c|}
\hline \multirow{3}{*}{$\begin{array}{l}\text { Table } 1.3 \\
\text { The entire } \\
\text { population }\end{array}$} & \multirow{3}{*}{$\begin{array}{c}\text { Population } \\
\text { as of } \\
\text { January } 1 \\
2018\end{array}$} & \multicolumn{3}{|c|}{ Changes during $2018(+,-)$} & \multirow{3}{*}{$\begin{array}{c}\text { Population } \\
\text { as of } \\
\text { January } 1 \\
2019\end{array}$} \\
\hline & & \multirow{2}{*}{$\begin{array}{c}\text { total } \\
\text { growth }\end{array}$} & \multicolumn{2}{|c|}{ including: } & \\
\hline & & & $\begin{array}{c}\text { natural } \\
\text { increase }\end{array}$ & $\begin{array}{c}\text { migration } \\
\text { growth }\end{array}$ & \\
\hline $\begin{array}{l}\text { Russian } \\
\text { Federation }\end{array}$ & 146880432 & -99712 & -224566 & 124854 & 146780720 \\
\hline $\begin{array}{l}\text { Southern Federal } \\
\text { District }\end{array}$ & 16441852 & 12698 & -37047 & 49745 & 16454550 \\
\hline
\end{tabular}


ISSN 2414-1143

Научный альманах стран Причерноморья. 2020. Том 22. № 2

\begin{tabular}{|l|c|c|c|c|c|}
\hline $\begin{array}{l}\text { North Caucasian } \\
\text { Federal District }\end{array}$ & 9823481 & 43267 & 68453 & -25186 & 9866748 \\
\hline $\begin{array}{l}\text { The Republic of } \\
\text { Dagestan }\end{array}$ & 3063885 & 22241 & 33249 & -11008 & 3086126 \\
\hline $\begin{array}{l}\text { The Republic of } \\
\text { Ingushetia }\end{array}$ & 488043 & 9350 & 6500 & 2850 & 497393 \\
\hline $\begin{array}{l}\text { The Kabardino- } \\
\text { Balkarian } \\
\text { Republic }\end{array}$ & 865828 & 391 & 3759 & -3368 & 866219 \\
\hline $\begin{array}{l}\text { The Karachay- } \\
\text { Cherkess } \\
\text { Republic }\end{array}$ & 466305 & -742 & 817 & -1559 & 465563 \\
\hline $\begin{array}{l}\text { The Republic of } \\
\text { North Ossetia- } \\
\text { Alania }\end{array}$ & 701765 & -2512 & 2000 & -4512 & 699253 \\
\hline $\begin{array}{l}\text { The Chechen } \\
\text { Republic }\end{array}$ & 1436981 & 19970 & 23528 & -3558 & 1456951 \\
\hline $\begin{array}{l}\text { Stavropol } \\
\text { Territory }\end{array}$ & 2800674 & -5431 & -1400 & -4031 & 2795243 \\
\hline
\end{tabular}

The source: [10]

Alarming conclusions stem from the analysis of the dynamics of the urban and rural population of the North Caucasus Federal District. As shown in Table 3, the urban population of the district increased in 2018 by 1.1\% (from 4920139 people up to 4947172 people), and the rural decreased by $0.8 \%$ (from 4924975 people up to 4919576 people). On average, in the Russian Federation, with a decrease in the total population by $0.1 \%$, the urban population increased by $0.1 \%$, and the rural population decreased by $0.6 \%$. In the neighboring Southern Federal District, the population increased by $0.1 \%$, while the urban population increased by $0.3 \%$, or 32299 people, and the rural population decreased by $0.3 \%$, or 19531 people. In the neighboring North Caucasus Federal District, with a total population growth of $0.4 \%$, the urban population increased by 54066 people, and the rural population decreased by 10799 people. That is, the comparative growth of the urban population of the North Caucasus Federal District, which is less than 1.6 times compared to the Southern Federal District, amounted to 1.6 times per year.

Table 3. Growth in the city and rural population of Russia and the regions of the South of Russia in 2018

\begin{tabular}{|c|c|c|c|c|c|c|}
\hline \multirow{3}{*}{ Table 1.6} & \multicolumn{3}{|c|}{ Population growth; person } & \multicolumn{3}{|c|}{ Population growth; \% } \\
\hline & \multirow{2}{*}{$\begin{array}{c}\text { The } \\
\text { entire } \\
\text { population }\end{array}$} & \multicolumn{2}{|c|}{ including: } & \multirow{2}{*}{$\begin{array}{c}\text { The } \\
\text { entire } \\
\text { population }\end{array}$} & \multirow[t]{2}{*}{ urban } & \multirow[t]{2}{*}{ rural } \\
\hline & & urban & rural & & & \\
\hline $\begin{array}{l}\text { Russian } \\
\text { Federation }\end{array}$ & $\begin{array}{r}-99 \\
712\end{array}$ & $\begin{array}{l}126 \\
634\end{array}$ & $\begin{array}{r}-226 \\
346\end{array}$ & $-0,1$ & 0,1 & $-0,6$ \\
\hline $\begin{array}{l}\text { Southern } \\
\text { Federal District }\end{array}$ & $\begin{array}{r}12 \\
698\end{array}$ & $\begin{array}{r}32 \\
229\end{array}$ & $\begin{array}{l}-19 \\
531\end{array}$ & 0,1 & 0,3 & $-0,3$ \\
\hline $\begin{array}{l}\text { North } \\
\text { Caucasian } \\
\text { Federal District }\end{array}$ & $\begin{array}{r}43 \\
267\end{array}$ & $\begin{array}{r}54 \\
066\end{array}$ & $\begin{array}{r}-10 \\
799\end{array}$ & 0,4 & 1,1 & $-0,8$ \\
\hline $\begin{array}{l}\text { The Republic of } \\
\text { Dagestan }\end{array}$ & $\begin{array}{r}22 \\
241\end{array}$ & $\begin{array}{r}13 \\
039\end{array}$ & $\begin{array}{r}9 \\
202\end{array}$ & 0,7 & 0,9 & 0,7 \\
\hline $\begin{array}{l}\text { The Republic of } \\
\text { Ingushetia }\end{array}$ & $\begin{array}{r}9 \\
350 \\
\end{array}$ & 5942 & $\begin{array}{r}3 \\
408 \\
\end{array}$ & 1,9 & 2,2 & $-22,0$ \\
\hline $\begin{array}{l}\text { The Kabardino- } \\
\text { Balkarian } \\
\text { Republic }\end{array}$ & 391 & -336 & 727 & 0,0 & $-0,1$ & 0,2 \\
\hline The Karachay- & - & 242 & -984 & $-0,2$ & 0,1 & 0,0 \\
\hline
\end{tabular}




\begin{tabular}{|l|r|r|r|r|r|r|}
\hline Cherkess & 742 & & & & & \\
Republic & -2 & & -1 & & & \\
\hline The Republic of & 512 & -992 & 520 & $-0,4$ & $-0,2$ & $-0,3$ \\
North Ossetia- & 19 & 33 & -13 & & & \\
Alania & 970 & 704 & 734 & 1,4 & 6,7 & 1,4 \\
\hline The Chechen & -5 & 2467 & -7 & $-0,2$ & 0,2 & $-0,3$ \\
Republic & 431 & 898 & & $-0,2$ & \\
\hline Stavropol & & & & & & \\
Territory &
\end{tabular}

The source: Population size and migration of the Russian Federation in 2018 (statistical bulletin). Moscow, Rosstat, 2019.

Comparing the migration growth (decline) rates of the population in Russia, the Southern Federal District and the North Caucasus Federal District, as well as its regions, it can be concluded that the migration outflow indicators in the North Caucasus Federal District as a whole are 2.6, which is almost three times higher than the Russian average. The highest rate of migration decline, as shown in Table 4, was observed in the Republic of North Ossetia-Alania. It amounted to 6.4. Here, the highest migration decline rate of the rural population was also observed (8.1), despite the fact that on average in Russia it amounted to 1.9., and in the rural population of the Southern Federal District, zero growth was recorded. Following North Ossetia, Dagestan stands in the ranking of negative migration per 1000 people: the total migration growth rate here was 3.6, and the migration decline rate of the rural population was 6.9 in 2018.

Table 4. Migration growth rates of the population of Russia and the regions of the South of Russia in 2018

\begin{tabular}{|l|c|c|c|}
\hline \multirow{3}{*}{ Table 1.10 } & \multicolumn{2}{|c|}{ Migration growth rates per 1,000 people } \\
\cline { 2 - 4 } & \multicolumn{2}{|c|}{ including: } \\
\cline { 2 - 4 } & $\begin{array}{c}\text { the entire } \\
\text { population }\end{array}$ & urban & rural \\
\cline { 3 - 4 } & 0,9 & 1,8 & $-1,9$ \\
\hline Russian Federation & 3,0 & 4,8 & 0,0 \\
\hline Southern Federal District & $-2,6$ & $-0,3$ & $-4,8$ \\
\hline North Caucasian Federal District & $-3,6$ & 0,4 & $-6,9$ \\
\hline The Republic of Dagestan & 5,8 & 10,4 & 0,1 \\
\hline The Republic of Ingushetia & $-3,9$ & $-4,6$ & $-3,1$ \\
\hline The Kabardino-Balkarian Republic & $-3,3$ & $-1,3$ & $-4,9$ \\
\hline The Karachay-Cherkess Republic & $-6,4$ & $-5,5$ & $-8,1$ \\
\hline The Republic of North Ossetia-Alania & $-2,5$ & $-3,8$ & $-1,7$ \\
\hline The Chechen Republic & $-1,4$ & 1,1 & $-5,0$ \\
\hline Stavropol Territory & & \\
\hline
\end{tabular}

Источник: [11]

Considering the total migration growth of the population in terms of age, it should be noted that migration is economic in nature, since from the total migration outflow of the population of the North Caucasus Federal District to 25 thousand people almost 17.5 thousand people are people of working age.

The highest indicators of negative migration among the regions of the North Caucasus Federal District were recorded in the Republic of Dagestan, only 7.2 thousand people left the region, the Stavropol Territory is in the second place, about 3.7 thousand people of working 
age left this territory. The third place is taken by North Ossetia, from which more than 3 thousand people of working age migrated.

The Federal Center understands that in the conditions of quarantine and self-isolation of consumers, the risks of not just temporary shutdown, but bankruptcy were experienced by all service enterprises, most of which belong to small business; and that it is a small business that provides employment to an overwhelming number of regions of Russia. It is also clear that without the development of infrastructure and regional economic support programs, unemployment is likely to rise sharply in many regions, and that only programmatic measures for supporting business can contribute to increasing demand for labor and smoothing migration outflows, but the sharp drop in tax revenues to the Federal Budget and regional budgets is likely to welcome the need to tighten control over cost increases.

Table 5. Total migration growth of the population of Russia and the regions of the South of Russia in 2018

\begin{tabular}{|l|c|c|c|c|}
\hline \multirow{2}{*}{ Table 2.11 } & \multicolumn{3}{|c|}{ Total population migration growth } \\
\cline { 2 - 5 } & in total & \multicolumn{2}{|c|}{ including those under the age } \\
\cline { 2 - 5 } & & under working-age & working-age & over working-age \\
\hline Russian Federation & $\mathbf{1 2 4} \mathbf{8 5 4}$ & $\mathbf{2 1 9 2 1}$ & $\mathbf{9 1 4 4 6}$ & $\mathbf{1 1 4 8 7}$ \\
\hline Southern Federal District & $\mathbf{4 9 7 4 5}$ & $\mathbf{7 8 6 9}$ & $\mathbf{3 1 3 1 2}$ & $\mathbf{1 0 5 6 4}$ \\
\hline $\begin{array}{l}\text { North Caucasian Federal } \\
\text { District }\end{array}$ & $\mathbf{- 2 5 1 8 6}$ & $\mathbf{- 5 9 1 2}$ & $\mathbf{- 1 7 4 4 1}$ & $\mathbf{- 1 8 3 3}$ \\
\hline The Republic of Dagestan & -11008 & -3375 & -7254 & -379 \\
\hline $\begin{array}{l}\text { The Republic of } \\
\text { Ingushetia }\end{array}$ & 2850 & 232 & 2021 & 597 \\
\hline $\begin{array}{l}\text { The Kabardino-Balkarian } \\
\text { Republic }\end{array}$ & -3368 & -477 & -2393 & -498 \\
\hline $\begin{array}{l}\text { The Karachay-Cherkess } \\
\text { Republic }\end{array}$ & -1559 & -429 & -823 & -307 \\
\hline $\begin{array}{l}\text { The Republic of North } \\
\text { Ossetia-Alania }\end{array}$ & -4512 & -758 & -3037 & -717 \\
\hline The Chechen Republic & -3558 & -1074 & -2265 & -219 \\
\hline Stavropol Territory & -4031 & -31 & -3690 & -310 \\
\hline
\end{tabular}

Источник: [11]

According to the study of the ACRA rating agency, Russian regions are likely to solve the problem of budget deficits by reducing costs or borrowings [9]. However, these measures will actually leave small businesses without targeted support, the latter provide up to half of employment in most regions of the North Caucasus Federal District. According to the latest stats, the total number of employees in Russia is about 72 million people. Among them 32 million people are employed in large and medium-sized enterprises, and about 40 million people, or $55.55 \%$, are employed in small enterprises [10]. However, it is in this segment that the prospects for direct assistance from the State are uncertain and ghostly, and that is why it is possible to predict an increase in interregional migration of working-age population from the small business sector.

Obviously, due to the crisis, income from personal income tax will significantly decrease, which, again, in many North Caucasus regions provides up to $50 \%$ of income, as well as from other regional taxes and payments for which deferrals or privileges are provided (income tax, property tax, rent and a number of others). And in this situation, it is better to increase direct assistance in the form of grants, subsidizing the interest rate of leasing and developing programs to support youth, family, innovative and Internet business for both 
existing and newly created small businesses. Otherwise, the current outflow of population to large cities, even without job security, will increase sharply in the coming years, and all the problems mentioned above will worsen. Such support is quite possible due to the reduction of non-priority costs and the concentration of costs on supporting regional business.

To increase employment in the territorial subjects of the North Caucasus Federal District of the Russian Federation, a number of proposals have been formulated: an increase in self-employment, which is possible, for example, within the framework of federal programs and the state program "Development of the North Caucasus Federal District," especially federal targeted programs aimed at the socio-economic development of each territorial subject of the North Caucasus Federal District until 2025; active development of programs of support of small business in the service industry where for the beginning of 2019 more than a half of the working population of the North Caucasus is really occupied within the subprograms of the state program "Development of the North Caucasian Federal District" directed to implementation of investment projects of North Caucasus federal district, development of a tourist and recreational cluster in the North Caucasian Federal District, the accelerated development of year-round tourist and recreational complexes of North Caucasus federal district, a medical cluster in Caucasian Mineral Waters area; organization and implementation of interregional employment programs for young and mobile people of the North Caucasus Federal District regions to the regions of Russia where there is a lack of workspaces.

\section{Лumepamypa}

1. Джиоев A.B. Анализ текущей ситуации на рынке труда Северо-Кавказского федерального округа/ Управление экономическими и социальными системами региона Сборник научных трудов. Под ред. С.Ф. Дзагоева. Владикавказ, 2019. C.166-172.

2. Европа подсчитала убытки от коронавируса. Худшие прогнозы сбываются. https://news.mail.ru/economics/41619600/

3. Занятость и безработица в Российской Федерации в январе 2020 года (по итогам обследования рабочей силы). https://gks.ru

4. И снова коронавирус. Насколько ОЭСР ухудшила прогноз роста мировой экономики в 2020 году. https://baltnews.ee/ekonomika_online_novosti/20200309/1018380620/I

5. Мир выходит из карантина, но не из кризиса/.https://news.mail.ru/politics/41881493/

6. Мировой экономике грозит кризис столетия, предупредил МВФ. Но все оказалось еще хуже. https://news.mail.ru/economics/41754352/

7. Рог изобилия. https://news.mail.ru/economics/41990443/

8. Росстат сообщил о 800 тыс. новых безработных в нерабочем апреле. https://www.rbc.ru/economics/26/05/2020/5ecd298c9a79473f80719596

9. Субъектный подход: регионы предложили свои меры поддержки бизнеса. https://iz.ru/999337/dmitrii-grinkevich/subektnyi-podkhod-regiony-predlozhili-svoimery-podderzhki-biznesa

10. Труд и занятость в России в 2019. М., Росстат, 2019.

11. Численность и миграция населения Российской Федерации в 2018 году (статистический бюллетень). М., Росстат, 2019.

12.Эксперт предсказал рост безработицы в России до 20 млн человек/ Секрет Фирмы от 03.06.2020.https://secretmag.ru/news/ekspert-predskazal-rost-bezraboticyv-rossii-do-20-mln-chelovek.htm 
13. Dzhioev A. Population employment as a development factor of the socio-demographic processes in the Northern Caucasus regions of Russia // Научный альманах стран Причерноморья. 2019. № 2 (18). С. 39-47

14.Dzhioev A. The employment impact on the region external migration//Научный альманах стран Причерноморья. 2019. № 3 (19). С. 11-19.

15. Gross Domestic Product 2019. The World Bank. https://gtmarket.ru/ratings/ratingcountries-gdp/rating-countries-gdp-info.

16. Gurieva L.K., Dzhioev A.V. International Economic Migration: Past and Present // Научный альманах стран Причерноморья. 2016. № 1 (5). С. 8-12.

\section{References}

1. Dzhioev A.V. Analiz tekushchei situatsii na rynke truda Severo-Kavkazskogo federalnogo okruga. Upravlenie ekonomicheskimi i sotsialnymi sistemami regiona Sbornik nauchnykh trudov. Pod redaktsiei S.F. Dzagoeva. [Analysis of the current situation in the labor market of the North Caucasus Federal District. Management of Economic and Social Systems of the Region. Collection of Scientific Papers. Edited by S.F. Dzagoev]. Vladikavkaz, 2019. pp. 166-172 (in Russian).

2. Evropa podschitala ubytki ot koronavirusa. Khudshie prognozy sbyvaiutsia. [Europe calculated losses from coronavirus. The worst predictions come true]. Available at: https://news.mail.ru/economics/41619600/ (in Russian).

3. Zaniatost i bezrabotitsa $v$ Rossiiskoi Federatsii $v$ ianvare 2020 goda (po itogam obsledovaniia rabochei sily). [Employment and unemployment in the Russian Federation in January 2020 (according to the results of the labor power survey)]. Available at: https://gks.ru (in Russian).

4. I snova koronavirus. Naskolko OESR ukhudshila prognoz rosta mirovoi ekonomiki v 2020 godu. [And again, the coronavirus. How much the OECD has worsened its forecast for global economic growth in 2020]. Available at: https://baltnews.ee/ekonomika_online_novosti/20200309/1018380620/I (in Russian).

5. Mir vykhodit iz karantina, no ne iz iz karantina, no ne iz krizisa. [The world comes out of quarantine, but not out of crisis]. Available at: https ://news.mail.ru/politics/41881493/

6. Mirovoi ekonomike grozit krizis stoletiia, predupredil MVF. No vse okazalos eshche khuzhe. [The world economy faces a crisis of the century, the IMF warned. But everything turned out to be even worse]. Available at: https://news.mail.ru/economics/41754352/ (in Russian).

7. Rog izobiliia. [Horn of plenty]. Available at: https://news.mail.ru/economics/41990443/

8. Rosstat soobshchil o 800 tys. novykh bezrabotnykh $v$ nerabochem aprele. [Rosstat reported 800 thousand new unemployed in non-working April]. Available at: https://www.rbc.ru/economics/26/05/2020/5ecd298c9a79473f80719596 (in Russian).

9. Subektnyi podkhod: regiony predlozhili svoi mery podderzhki biznesa. [Subjective approach: regions offered their measures to support business]. Available at: https://iz.ru/999337/dmitrii-grinkevich/subektnyi-podkhod-regiony-predlozhili-svoimery-podderzhki-biznesa (in Russian).

10. Trud i zaniatost v Rossii v 2019. [Labor and employment in Russia in 2019]. Moscow, Rosstat, 2019 (in Russian) (in Russian).

11. Chislennost i migratsiia naseleniia Rossiiskoi Federatsii v 2018 godu (statisticheskii biulleten). [Population size and migration of the Russian Federation in 2018 (statistical bulletin)]. Moscow, Rosstat, 2019 (in Russian).

12. Ekspert predskazal rost bezrabotitsy v Rossii do 20-mln chelovek. Sekret Firmy ot 03.06.2020. [The expert predicted an increase in unemployment in Russia to 20 
million people. The secret of the Company from 03.06.2020]. Available at: https://secretmag.ru/news/ekspert-predskazal-rost-bezraboticy-v-rossii-do-20-mlnchelovek.htm (in Russian).

13.Dzhioev A. Population employment as a development factor of the socialdemographic processes in the Northern Caucasus regions of Russia. Science Almanac of Black Sea Region Countries. 2019. No. 2 (18). pp. 39-47.

14.Dzhioev $A$. The employment impact on the region external migration. Science Almanac of Black Sea Region Countries. 2019. No. 3 (19). pp. 11-19.

15. Gross Domestic Product 2019. The World Bank. Available at: https://gtmarket.ru/ratings/rating-countries-gdp/rating-countries-gdp-info.

16. Gurieva L.K., Dzhioev A.V. International Economic Migration: Past and Present. Science Almanac of Black Sea Region Countries. 2016. No. 1 (5). pp. 8-12. 